\title{
Helping the world one 'like' at a time: The rise of the slacktivist
}

Freya Samuelson-Cramp and Elvira Bolat

\begin{abstract}
Much like the corporate sector, the charity and non-profit sector has adopted social media as one of their core engagement and fundraising tools. The online community has great power and has worked well for many brands; however, the extent to which this is benefitting the third sector is debatable. Is liking a non-profit organization on Facebook equal to donating money or running a marathon? A consumer's online interaction with a charity, e.g. liking or sharing social media content and pages, is sometimes referred to as 'slacktivism'. To date, studies on 'slacktivist' behavior in the social media context are limited to few conceptual papers. This study provides empirical insights into motivations and interactions of social media users towards non-profit and charity-related social media campaigns.
\end{abstract}

Keywords: non-profit and charity-related social media campaigns; slacktivism; theory of reasoned actions; big five personality factors; social media engagement.

\section{Introduction}

Over the last ten years social media has become a buzzword in all things business, psychology and global change. Guo and Saxton (2013) claim that social media platforms have paved a way for reaching and mobilizing new networks of community actors. These platforms further give a voice to issues that might otherwise have no airtime on traditional media (Lovejoy et al. 2012). The charity and non-profit sector has adopted social media as one of their core engagement and fundraising tools, grasping the great power of online communities, its vast reach and cost effectiveness (Lawrance 2013). 
However, the extent to which this platform is benefitting the sector is debatable. Is investment in social media marketing creating a monetary return, building a supporter base or just giving consumers a way to satisfy their conscience with minimal effort and effect? Do people feel that 'liking' a non-profit organization on Facebook is equal to donating money or running a marathon? Grummas (2015) reports that online supporters are not effectively changing anything but are merely showing tokens of appreciation by liking and sharing online charity-related campaigns. Also known as 'slacktivism'. Slacktivism is defined as “a willingness to perform a relatively costless token display of support for a social cause, with an accompanying lack of willingness to devote significant effort to enact meaningful change” (Kristofferson et al. 2014, p. 1149). Slacktivism is essentially driven by online communityparticipation in the low-cost online action and could be perceived as a form of online community volunteerism (Lee and Hsieh 2013).

Slacktivism is in itself a controversial subject. Khazan (2013) claimed that slacktivists should not be a concern to non-profit organizations, as they may have never had the intention to involve themselves with activist behaviors. A social media user could be engaging out of boredom or due to a participatory nature of the social media environment that drives group interactions, content creations and sharing, as well as belonging to certain type of online community (Khazan 2013). On the other hand slacktivism can be effective in showing solidarity through mass participation and raising awareness. Vie (2014) suggested that even when no tangible action results from a campaign, global awareness is still a great achievement and many slacktivists may develop into activists through this engagement. This is particularly important for charity and non-profit organizations that can benefit from the power of online communities' slacktivist behavior and generate higher number of future 'real’ civic actions, hence, socially responsible and philanthropic behavior. 
To date, studies on slacktivist behavior in a social media context are limited. Rotman et al.'s (2013) study discusses a process framework for slacktivist and activist behaviors on social media. However, with no empirical evidence obtained to illustrate, confirm or challenge the framework this cannot be used. Lee and Hsieh (2013) conducted a study of online petitions that explored pro and anti gun possession. They found that slacktivist behavior deters consumers from taking further action as they have already satisfied their altruistic needs. However, no other similar studies were conducted to demonstrate generality of results.

Whether slacktivism is seen in a positive or negative light, it is important to explore and understand the reasons behind the phenomenon so that charity and non-profit organizations can either encourage or discourage this behavior to the advantage of society by nurturing a philanthropic conduct and social responsibility. Adopting theories of reasoned actions and planned behavior together with Goldberg's big five personality factors, this study investigates the motivations and interactions of social media users towards non-profit social media campaigns, with particular interest in studying three types of behavior, namely slacktivism, activism and non-conformism.

\section{Theoretical background}

Traditionally, there are two categories of social media users in the context of charities and non-profit organizations, non-conformists and activists. Kristofferson et al. (2014) commented that there is little coverage on the understanding of the motivations behind the non-conformist behavior of social media users. A non-conformist can be described as a person who does not engage with or show their views towards non-profit and charity-related campaigns on social media, irrespective of their support offline. Using Goldberg's 5 personality factors, Ross et al. (2009) found consumers who rated high in conscientiousness were averse to engaging in this way on social media, which could explain non-conformists’ lack of engagement. On the other hand, perhaps non-conformists are not being reached by the 
right campaigns. Messing and Westwood (2012) raise the issue of social media filtering: where certain social groups of like-minded people share content between each other, keeping this content insular and prohibiting the content from reaching opposing social groups, socioeconomic groups or culturally diverse groups who may benefit from the content.

However, when addressing activists and slacktivists their opinions and demographics may be similar but are their actions of similar gravitas? Within newly proposed AMEC's (2016) integrated evaluation framework of social media marketing communications process, slacktivist behavior corresponds with awareness and reach marketing communication objectives. A consumer's interaction with charities and non-profit businesses by sharing and liking campaigns is based around the notion of 'slacktivism', whereas, an activist is someone who goes beyond liking, sharing and commenting and takes part in efforts like protests, fundraising or volunteering ('real' civic actions). Therefore, from a marketing communications perspective a bridge between slacktivist and activists represents conversion (AMEC 2016).

However, there may be scope for developing charity supporter's social media use, according to Guo and Saxton (2013, p. 4) “advocacy organizations failed to fully utilize the affordances of social media”. Existing viral campaigns, for example, Kony 2012 and ALS Ice Bucket Challenge 2015, highlight where users have not been utilized effectively and slacktivism has prevailed. It was easy for users to 'share' or 'like' the videos without investigating what they were actually supporting. The Invisible Children charity used a viral video, which asked viewers to lobby the US government to stand up against Ugandan Warlord Joseph Kony. The Kony 2012 campaign received copious amounts of support online but actualized into no physical action. Users who shared the video were then shocked to find out about many issues of the campaign and the charity, realizing they had automatically shared something on social media without knowing the true facts. The latter campaign was a viral social media 
challenge, where partakers would pour a bucket of water over their head and donate to charity, then challenge their friends to take part as well. However, the amount of people who took part was far greater than the amount of donations received, suggesting that partakers wanted to be involved but had little intention to donate to the cause.

Slacktivist behavior may also prevent further action as one has already satisfied their altruistic needs. Lee and Hsieh (2013) tested this issue using online petitions for and against gun possession. They found that when participants signed an online petition they were significantly more likely to donate to a related charity. However, when participants did not sign the petition, they went on to donate even more money to an unrelated charity. This could suggest that those who signed the petition compensated a proportion of their whole donation with signing the petition. However, Lee and Hsieh's (2013) research is specific to gun possession and further research should look into other types of issues.

As a relatively new behavior the research on slacktivism is scarce. However, Just Giving, an online donation platform, released a report (Just Giving 2015) on slacktivism revealing that a 'share' on social media is worth around eight USA dollars in donations and people were likely to donate once they had shared a charity's post, disproving the idea that slacktivists substitute donations for social media engagement. The report also found that people were more likely to share a friend's Just Giving page on Facebook if the message accepting their donation suggested they were helping a friend raise even more money. This could be due to higher levels of trust resulting from a positive perception of sources of online support as well as a closer link and association with causes which are shared among a friendship circle (Populus 2016). This suggests that influence by peers and sense of belonging to community stimulates slacktivist behavior. 
Recent studies have shown the effect Twitter has on changing non-profit advocacy (Guo and Saxton 2013) and also the effect of token support on further support (Kristofferson et al. 2014). The latter found that public token support does not increase meaningful support for social causes. Once a participant has participated in the token act, their desire to present themselves in a positive light has been satisfied and they may not increase their support for the cause (Kristofferson et al. 2014). However, an individual's value alignment with a charity can help to combat slacktivism by evolving their initial token support into more meaningful further support (Kristofferson et al. 2014).

It would be beneficial for charities to evolve slacktivists communities into activists to provide charities with more capital but most importantly to nurture social responsibility. Gächter and Fehr's (1999) findings suggest that this can be achieved through social approval incentives. Revealing the identity and contributions of each donor and making the donors discuss their contributions increased their giving, however, only for those who knew each other. Hence, online community-based campaign and communications should be considered. Andreoni and Petrie (2004) also found that revealing the identity of a donor as well as their contribution amount was necessary for giving to increase significantly. Rotman et al. (2013) have already created a process framework for slacktivist and activist behaviors on social media. According to Rotman et al. (2013), identification of the cause leads to a need for more knowledge and information about the cause, in which case social media supplies content to feed such need. The result of interaction with the content and with other social media users within communities or friendship circles can then drive either activist or slacktivist behaviors. No empirical evidence or test has been provided to support or challenge Rotman et al.'s (2013) framework. Moreover, it does not account for individual factors of potential donors' which affect awareness levels and engagement with charity-related social media content. To progress with identification of the motivations and factors that drive slacktivist, activist, and 
non-conformist behaviors, it is crucial to discuss early research into donating behaviors and donors' characteristics.

It is vital for charities to understand donors, their behaviors and motivations - to help maximize their worth. Adapting Goldberg's big five personality factors, many studies (Stroebe and Frey 1982; Brunel and Nelson 2000; Sargeant et al. 2006; Bekkers and Wiepking 2010) have explored this consumer type, in particular how donors' characteristics influence their engagement and how marketing tools affect them.

The first step in the relationship between a donor and a charity is sometimes the recognition of a need. This need will either be from the organization asking for help or from the donor who feels the need to support a cause (Bekkers and Wiepking 2010). The donor's awareness of need can be facilitated through features on the news or concerns raised in TV programs, for example, the amount of time spent watching charity and charitable cause-related television content increases the amount of relief donations (Bennett and Kottaszc 2000). However, Bekkers and Wiepking (2010) disagreed claiming that often donors do not actively seek opportunities to donate, but react to the needs of causes and solicitations from charitable organizations, suggesting that giving is more often initiated by a charity's 'call to action'.

Donor characteristics such as age, class, gender and religion also affect giving. Young professionals are likely to be uninterested in giving to charity (Kottasz 2004), but as their age increases so does their likeliness to give (Bennett 2003). Schervish and Havens (2001) showed that wealthier individuals give more to charity yet their motivations differ to those less wealthy, as implicit social contracts encourage investing a portion of excessive wealth to give opportunities to others. There is also disparity between genders: men are motivated by recognition whilst women are motivated by making a difference (Brunel and Nelson 2000). Religious convictions can also be a factor in a person's behavior. The Giving Institute 
reported (Coombs et al. 2008) that almost 33 percent of charitable gifts were given by religious congregations in 2006.

Personal values can affect giving. Bennett (2003) found that an individual's personal values correlated both positively and significantly with the charity's values. Bekker and Wiepking (2010) suggested that values make up a person's ideal world and to achieve this they support certain charities that can promote these values, for example, reducing poverty, welfare for animals or protecting the earth. In a social media context personal values could also be extended to online community values (Jung et al. 2014).

Sargeant at al. (2006) identified ‘demonstrable utility’ as the selfish economic considerations behind giving, such as supporting non-profits that will benefit themselves in the future or have done in the past. These donors may also base their donation amount depending on how visible the act is to others within their social group (Stroebe and Frey 1982). For example, organizations like Great Ormond Street Hospital Children’s Charity provide plaques next to hospital bedrooms, inscribed with fundraiser's names. Beatty et al. (1999) also found that higher valued donors were motivated by two impulses: to feel better about themselves (selfrespect givers) or to maintain or enhance relationships (relationship givers), for example, improving their social status through appearing altruistic. Although Beatty et al.'s (1999) research is outdated; it demonstrates that this type of motivation has been seen consistently through charitable giving. Jonas et al. (2002) found that in the USA mortality salience, the anxiety of death anticipation increased an individual's donations to charity. In most cases such donations were only distributed to USA projects rather than international projects, showing a selfish concern to benefit the donor's own society above others. This behavior could be extended and applied to social media community users that essentially explained slacktivism or activism behavior. 
Bekkers and Wiepking (2010) postulated that giving comes from an almost automatic emotional response. This produces positive moods such as satisfying a need to show gratitude or to be moral. It also can alleviate bad moods, as not giving would fill a person with shame or guilt. Smith and McSweeney (2007) showed that respondents who anticipated feeling guilty from not giving were more likely to donate. Demonstrating friendliness and interest in the donor's wellbeing is more likely to encourage them to donate when requested (Bekkers and Wiepking 2010).

Alternatively, the motivation to donate to some causes can stem from whether friends and family have been affected by it (Sargeant 1999). Kotler and Clarke (Sargeant et al. 2006) claim this is a common source of donations for healthcare organizations, usually when someone is giving in memoriam. Cancer Research UK's 'Race for Life' supports the same concept, asking runners to raise money for a loved one who has been affected by cancer.

Donors who are truly altruistic are not motivated by selfish concerns; they simply want to better the world around them. Vesterlund et al. (2008) argues that the pure altruism model shows that the only motive for giving is a concern for securing the charity's efforts. According to Alexander et al. (1991) generativity, “a psychological and developmental process through which people face the fact of ageing and death”, is a good example of altruism as the concern for being remembered is not important.

Despite this extensive research into the motivations and factors behind donating, many of these beliefs are of a pre-internet age or have not been tested in the social media context. It is possible that they have changed, as online culture has grown worldwide. To the best of our knowledge there is little research into how above discussed motives and factors have been transferred into the online world. By merging together offline motivations for donating and 
theories surrounding social media use, this paper investigates nine hypotheses listed below (Table 1) and summarized as a conceptual framework in Figure 1.

\section{Table 1. List of hypotheses}

H1: Personality attributes lead to motivations (demonstrable, psychological, altruism and familial link) for supporting charities

H2: Personality attributes lead to different supporter type behavior (activists, slacktivist, non-conformist)

H3: Different motivations (demonstrable, psychological, altruism and familial link) for supporting charities lead to different supporter type behavior (activists, slacktivist, nonconformist)

H4: Motivations (demonstrable, psychological, altruism and familial link) for supporting charities influence attitudes towards social media

H5: Motivations (demonstrable, psychological, altruism and familial link) for supporting charities influence attitudes towards charity-related social media campaigns

H6: The subjective norms have a positive impact on attitudes towards charity-related social media campaigns

H7: The subjective norms will lead to different supporter type behavior (activists, slacktivist, non-conformist)

H8: Attitudes towards social media moderates relationships between motivations (demonstrable, psychological, altruism and familial link) for supporting charities and attitudes towards charity-related social media campaigns

H9: Attitudes towards charity-related social media campaigns lead to different supporter type behavior (activists, slacktivist, non-conformist) 


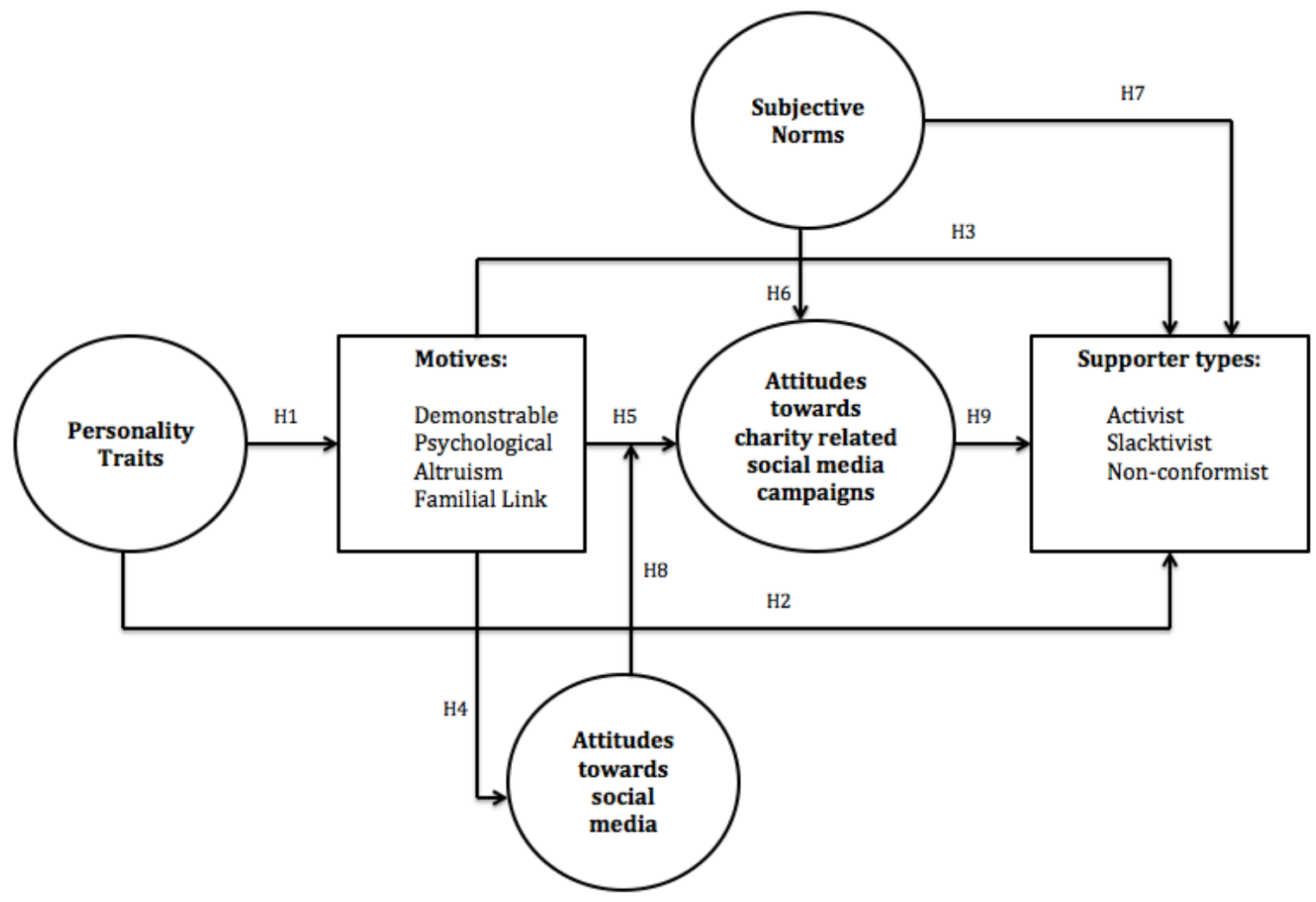

\section{Research method}

Self-administered surveys were deemed the most suitable method for collecting data for the research due to ability to delve into what the participant thinks and believes to explain cognitive processes like opinions and behaviors with more validity (Maylor and Blackmon 2005). This type of survey also accommodates the use of anonymity and confidentiality, which is imperative to the research as questions surrounding charitable support and donations can be quite intrusive in nature. This may have provided the research with more genuine responses from participants as they would not be affected by social desirability bias which can create issues of validity in the results (Fisher 1993). This was important when exploring participants' relationships with charity and donations as there is a lot of social pressure around supporting charities (Reyniers and Bhalla 2013). 
The survey was distributed online via Facebook over a three-week period in March 2016. The research was based on Facebook use and, therefore recruited participants through the platform. The survey was designed using PollDaddy.com as it allowed the use of images, a larger number of questions and wider range of survey styles compared to other providers. Participants have been accumulated using a combination of two non-probability methods, a convenience and snowballing sampling method, using Facebook as a promotional tool to get the survey out to as many participants as possible. This resulted in, 154 completed surveys from a variety of social circles on Facebook. The sample was 34 percent male and 66 percent female and 78 percent aged 18-34. The income levels were varied, 41 percent in the $<£ 10,000$ income bracket; 18 percent in the $£ 20,000-£ 30,000$ income bracket; 10 percent in the $£ 30,000-£ 40,000$ bracket and 31 percent in the $>£ 40,000$ income bracket.

Designed in English, the survey employed the use of a 48-item questionnaire to identify demographics, personality, social media use and constructs based on motivation and processes formulated from the literature reviewed. Each variable/construct was assessed using three items or more to increase validity and adopted a 5-point Likert scale. Personal attributes were tested using an adaption of The Big Five Personality test by Gosling et al. (2003). Items to test the motivations and attitudes towards participants' engagement with charities social media campaigns and content were adapted from previous literature (Seidman 2013; Sargeant et al. 2006; Grau and Folse 2007; Flora and Maibach 1990; Pikkarainen et al. 2004; Fielding et al. 2008; Leek and Christodoulides 2009). Results of internal consistency analysis showed Cronbach’s Alpha value for each variable is greater than 0.7 indicating high scale of reliability. Categorization of supporter types (slacktivist, activist and non-conformist - each consisting of three items) was based on Mano (2014).

\section{Results and discussion}

We present means and standard deviations for main variables in Table 1. 
Table 1. Means and standard deviations

\begin{tabular}{|l|r|r|}
\hline \multicolumn{1}{|c|}{ Variable } & Mean & $\begin{array}{r}\text { Standard } \\
\text { deviation }\end{array}$ \\
\hline Attitudes towards social media & 3.7 & 0.81 \\
\hline Attitudes towards charity-related social media & 3.6 & 0.71 \\
\hline Subjective Norm & 3.2 & 0.7 \\
\hline Motives & & \\
\hline Demonstrable motive & 2.7 & 0.81 \\
\hline Familial motive & 3.1 & 0.95 \\
\hline Emotional and psychological motives & 3 & 0.82 \\
\hline Altruistic motive & & 0.83 \\
\hline Personality Traits & 5.4 & 0.91 \\
\hline Extroversion & 5.5 & 0.68 \\
\hline Agreeableness & 5.7 & 0.802 \\
\hline Conscientiousness & 5.1 & 0.89 \\
\hline Emotional stability & 5.6 & 0.78 \\
\hline Openness to experiences & & 0.99 \\
\hline Supporter Types & & 0.56 \\
\hline Slacktivist & & \\
\hline Activist & & \\
\hline Non-conformist & & \\
\hline Note: Ne154 & & \\
\hline
\end{tabular}

Note: $\mathrm{N}=154$

Firstly, in investigating the relationship between the personality traits and the motivations towards supporting a charity (hypotheses 1-3), the most significant, however weak in its strength, relationships were shown between (1) demonstrable motives and extroversion; (2) familial motivations and conscientiousness. Secondly, in terms of categorization by supporter types, overall, 118 participants showed activist behavior, ninety-two showed slacktivist behavior and fifty-three participants showed non-conformist behavior. 
Activists rated the highest on emotional stability and extraversion compared to the other supporter types, which would be expected of someone who wanted to be physically involved in altruistic behaviors and partake in fundraising events. Slacktivists were the most open to experiences, agreeable and conscientious, which would suggest they do feel a moral duty to help but perhaps are encouraged to act by others' requests or from the excitement of doing something new. Slacktivists truly demonstrate typical behaviors of online community members (Jung et al. 2014).

Non-conformists did not rate higher than the other types of behaviors on any positive traits however did have the highest percentage of people who were low in conscientiousness and openness to experiences. This is predictable as non-conformists do not partake in supporting charities online, which could be due to a lack of caring about moral duties or the need to be involved. It would be, however, interesting to investigate further non-conformists' social media profiling and belonging to online communities in particular.

Comparisons between motivations and supporter types show that all supporter types believed they were not influenced by emotional or psychological motivations to support charities on social media. This could be an effect of the media channel used (social media) or perhaps participants are cynical about emotional or guilt marketing (Cotte et al. 2005). Contrary to our beliefs slacktivists rated higher on altruistic motivations than activists. However, predictably non-conformists disagreed the most with being motivated by altruism. There was little agreement to being demonstrably motivated across all types of behavior, especially for non-conformists who gave no agreement. Familial motivations were the strongest influencer of supporting charities on social media which may suggest this type of behavior is used to create a supportive online community for a friend or family or support is often given in honor of a passed relative. 
In terms of personality attributes, for activists and slacktivists alike, emotional stability was the least recognized personality trait, which may mean they are more affected by their emotions than non-conformists. Activists were also most likely to have extrovert personalities, and such personalities use social media to present their 'real' self rather than an 'ideal' self (Michikyan et al. 2014). It is unsurprising that all types of behavior rated as extroverts and most highly open to experiences as these traits are both positively linked with social media use (Correa et al. 2010). Agreeableness has been consistently linked to altruistic and pro-social behavior (Corr et al. 2015) and has been further supported by our research. Agreeableness appeared to be the most prominent in slacktivists rather than activists; this is relevant as it involves being compliant with rules and behavior within certain online communities and friendship circles. Sharing posts and becoming involved in viral campaigns such as ALS Ice Bucket Challenge 2015 are behaviors that depend on such compliance.

When testing hypotheses 4-9 we found that the demonstrable motive was the only significant variable to impact on attitudes towards social media. The familial motive proved to have the most significant relationship with the attitudes towards charity-related social media campaigns. The second most significant motive in impacting attitudes towards charity-related social media campaigns was demonstrable motive but in combination with the familial motive the effect has increased drastically.

The subjective norm, peers pressure and influence, was found to be significant driver towards positive attitudes towards charity-related social media campaigns. But in relation to differences across types of behavior, we found activist behaviors to not be significantly impacted by the subjective norm. Contradicting Seidman's (2013) findings, our study found the subjective norm to have the strongest correlation with slacktivist behavior and, therefore, suggests slacktivists are somewhat influenced by the perceived pressure from those around them. This is surprising; however, this should be studies further within the context of online 
communities where social pressure should have a higher degree of impact on community members' actions and behavior (Jung et al. 2014). The non-conformists, on the other hand, were found to have the most significant but negative relationship with the subjective norm out of all types of behavior. This raises a question whether non-conformists are these social media users who do not belong to any online community.

When testing moderating effect of attitudes towards social media in hypothesis 8 we found no significant impact on relationships between motivations (demonstrable, psychological, altruism and familial link) for supporting charities and attitudes towards charity-related social media campaigns. Finally, we found no significant relationships between attitudes towards charity-related social media campaigns and three types of behavior. Empirical evidence from our research shows that slacktivists are strongly motivated by the familial link and by emotional and psychological motives. Hence, it is not surprising to see that we found no relationship between attitudes towards charity-related social media campaigns and slacktivist behaviour. If those who are slacktivist are not emotionally engaged with a charity, they may be engaging with content out of boredom, because they have been prompted by a peer or due to the emotional and aesthetic premises of content. However, those, with activist behaviors, were the most influenced group by the attitudes towards charity-related social media campaigns. This raises a question whether work with online communities can foster slacktivist behavior, whereas charity-related social media campaigns can then convert slacktivist behavior into activism, hence socially responsible activities.

Overall, this study highlights that the non-profit sector deals with diverse audience categories on social media, hence, objectives and communication tactics should be mapped against each individual category. Supporting and socially responsible behavior, as proposed by Rotman et al. (2013), requires awareness of cause and a stronger message that recognizes the need to support the cause. Hence, charity-related campaigns require detailed and loop-based planning 
to continuously include educational content that can emotionally connect the social media audience with the cause as well as evoking a need to support the charity. Following this, third sector organizations need to engage in a conversion process by implementing targeted solutions around the familiarity dimension, direct linkages with specifically profiled audience as well as indirect mapping of interlinks within the social media friendship links. Perhaps in this case, communicating with certain online communities might result in higher engagement due to unavoidable sharing of values among members of online communities. Table 2 presents overall outcomes of hypotheses testing.

Table 2. Overall outcomes of hypotheses testing

\begin{tabular}{|l|l|}
\hline \multicolumn{1}{|c|}{ Hypothesis } & \multicolumn{1}{|c|}{ Conclusion } \\
\hline $\begin{array}{l}\text { H1: Personality attributes lead to motivations (demonstrable, } \\
\text { psychological, altruism and familial link) for supporting } \\
\text { charities }\end{array}$ & Partially supported \\
\hline $\begin{array}{l}\text { H2: Personality attributes lead to different supporter type } \\
\text { behavior (activists, slacktivist, non-conformist) }\end{array}$ & Supported \\
\hline $\begin{array}{l}\text { H3: Different motivations (demonstrable, psychological, } \\
\text { altruism and familial link) for supporting charities lead to } \\
\text { different supporter type behavior (activists, slacktivist, non- } \\
\text { conformist) }\end{array}$ & Supported \\
\hline $\begin{array}{l}\text { H4: Motivations (demonstrable, psychological, altruism and } \\
\text { familial link) for supporting charities influence attitudes } \\
\text { towards social media }\end{array}$ & Partially supported \\
\hline $\begin{array}{l}\text { H5: Motivations (demonstrable, psychological, altruism and } \\
\text { familial link) for supporting charities influence attitudes } \\
\text { towards charity-related social media campaigns }\end{array}$ & Partially supported \\
\hline $\begin{array}{l}\text { H6: The subjective norms have a positive impact on attitudes } \\
\text { towards charity-related social media campaigns }\end{array}$ & Supported \\
\hline $\begin{array}{l}\text { H7: The subjective norms will lead to different supporter type } \\
\text { behavior (activists, slacktivist, non-conformist) }\end{array}$ & Partially supported \\
\hline
\end{tabular}




\begin{tabular}{|l|l|}
\hline $\begin{array}{l}\text { H8: Attitudes towards social media moderates relationships } \\
\text { between motivations (demonstrable, psychological, altruism } \\
\text { and familial link) for supporting charities and attitudes towards } \\
\text { charity-related social media campaigns }\end{array}$ & Unsupported \\
\hline $\begin{array}{l}\text { H9: Attitudes towards charity-related social media campaigns } \\
\text { lead to different supporter type behavior (activists, slacktivist, } \\
\text { non-conformist) }\end{array}$ & Unsupported \\
\hline
\end{tabular}

\section{Conclusion, research implications and limitations}

As technology and its consumers evolve it is important for charities to evolve also to remain connected and relevant in today's society. Drawing from the research and past literature, it is clear that slacktivists can still be valuable supporters and perhaps should be nurtured in the hope that they may give more tangible support in the future in charity and non-profit sector's goal to sustainably growing future activists and nurturing social responsibilities. It could be possible that slacktivists are only held back by a lack of time or effort and charities and nonprofit organizations should still aim to build relationships with these supporters to invest in current and future generations who care about social causes and issues and are willing to support organizations as well as spread awareness and activist behavior. The findings suggest that to increase the effectiveness of their social media campaigns charities should, in addition to using emotional tactics, focus on the notion of supporting online communities which slacktivists are part of. This, however, requires further investigation.

The main limitations encountered in this study were sampling issues. Although many of the findings were significant across a rather small sample (154 responses), previous research has examined the differences that gender, age and cultural background account for in their findings. As the sample was not collected to represent these characteristics equally many of the findings may be biased. However, this could provide an area to focus on within future 
research and to conduct a similar study which is more representative of the population across characteristics and size.

Furthermore, the results collected on personality traits and motivations tended to cluster around positive or socially desirable variables. There were few participants who rated themselves highly on unappealing traits such as neuroticism or introversion, this may be a bias effect from the use of self -reported questionnaires or may suggest the sample was too similar. Although, this research has identified differences between slacktivists, activists and non-conformists, more research is needed to support these findings.

\section{Bibliography}

Alexander, Baine B., Robert L. Rubinstein, Marcene Goodman, and Mark Luborsky. 1991. "Generativity in Culture Context: The Self, Death and Immortality as Experienced by Older American Women." Ageing and Society 11:417-442. https://doi.org/10.1017/S0144686X00004384.

AMEC. 2016. Integrated evaluation framework. AMEC: London. http://amecorg.com/amecframework/ Accessed May 2, 2017.

Andreoni, James, and Ragan Petrie. 2004. "Public goods experiments without confidentiality: a glimpse into fund-raising." Journal of public Economics 88:1605-1623. https://dx.doi.org/10.1016/S0047-2727(03)00040-9.

Beatty, Sharon E., Lynn R. Kahle, and Pamela Homer. 1991. "Personal values and gift-giving behaviors: A study across cultures." Journal of Business Research 22:149-157. http://dx.doi.org/10.1016/0148-2963(91)90049-4. 
Bekkers, René, and Pamala Wiepking. 2010. "A literature review of empirical studies of philanthropy: Eight mechanisms that drive charitable giving." Nonprofit and Voluntary Sector Quarterly. http://dx.doi.org/10.1108/09653560010361393.

Bennett, Roger, and Kottasz, Rita. 2000. "Emergency fund-raising for disaster relief." Disaster Prevention and Management: An International Journal 9:352-360.

Bennett, Roger. 2003. "Factors underlying the inclination to donate to particular types of charity." International Journal of Nonprofit and Voluntary Sector Marketing 8:12-29. http://dx.doi.org/10.1002/nvsm.198.

Bertot, John C., Paul T. Jaeger, and Justin M. Grimes. 2010. "Using ICTs to create a culture of transparency: E-government and social media as openness and anti-corruption tools for societies." Government information quarterly 27:264-271. http://dx.doi.org/10.1016/j.giq.2010.03.001. Accessed October 1, 2015.

Brunel, F. F., and Nelson, M. R. 2000. "Explaining gendered responses to "help-self" and "help-others" charity ad appeals: The mediating role of world-views." Journal of Advertising 29:15-28. http://dx.doi.org/10.1080/00913367.2000.10673614.

Coombs, Joseph E., Abbie J. Shipp, and Lisa Christensen. 2008. "Entrepreneur as change agent: Antecedents and moderators of individual-level philanthropic behavior." Journal of $\begin{array}{llll}\text { Economic } & \text { Behavior } & \text { Ond } & \text { Organization }\end{array}$ http://dx.doi.org/10.11648/j.ijebo.20150304.11 .

Corr, Philip J., Shaun P. Hargreaves Heap, Charles R. Seger, and Kei Tsutsui. 2015. "An experiment on individual 'parochial altruism'revealing no connection between individual 'altruism’and individual 'parochialism'." Frontiers in psychology 6. http://dx.doi.org/10.3389/fpsyg.2015.01261. 
Correa, Teresa, Amber Willard Hinsley, and Homero Gil De Zuniga. 2010. "Who interacts on the Web?: The intersection of users’ personality and social media use." Computers in Human Behavior 26:247-253. http://dx.doi.org/10.1016/j.chb.2009.09.003.

Cotte, June, Robin A. Coulter, and Melissa Moore. 2005. "Enhancing or disrupting guilt: The role of ad credibility and perceived manipulative intent." Journal of Business Research 58:361-368. http://dx.doi.org/10.1016/S0148-2963(03)00102-4.

Fielding, Kelly S., Rachel McDonald, and Winnifred R. Louis. 2008. "Theory of planned behaviour, identity and intentions to engage in environmental activism." Journal of environmental psychology 28:318-326. http://dx.doi.org/10.1016/j.jenvp.2008.03.003.

Fisher, Robert J. 1993. "Social desirability bias and the validity of indirect questioning." Journal of consumer research 20: 303-315. http://dx.doi.org/10.1086/209351.

Flora, June A., and Edward W. Maibach. 1990. "Cognitive Responses to AIDS Information The Effects of Issue Involvement and Message Appeal." Communication research 17:759774. http://dx.doi.org/10.1177/009365029001700603.

Goatman, Anna K., and Barbara R. Lewis. 2007. "Charity E- volution? An evaluation of the attitudes of UK charities towards website adoption and use." International Journal of Nonprofit and Voluntary Sector Marketing 12:33-46. http://dx.doi.org/10.1002/nvsm.272.

Gosling, Samuel D., Peter J. Rentfrow, and William B. Swann. 2003. "A very brief measure of the Big-Five personality domains." Journal of Research in personality 37:504-528. http://dx.doi.org/10.1016/S0092-6566(03)00046-1.

Grau, Stacy Landreth, and Judith Anne Garretson Folse. 2007. "Cause-related marketing (CRM): The influence of donation proximity and message-framing cues on the less-involved 
consumer." Journal of Advertising 36:19-33. http://dx.doi.org/10.2753/JOA00913367360402.

Grummas, Emma. 2015. “Likes don't save lives - lessons from a social media campaign”. The Guardian, 23 September 2015. http://www.theguardian.com/sustainable-business/likesdont-save-lives-unicef-social-media. Accessed September 15, 2015.

Gächter, Simon, and Ernst Fehr. 1999. "Collective action as a social exchange." Journal of economic behavior \& organization 39:341-369. http://dx.doi.org/10.1016/S01672681(99)00045-1.

Guo, Chao, and Gregory D. Saxton. 2013. "Tweeting social change: How social media are changing nonprofit advocacy." Nonprofit and Voluntary Sector Quarterly 1-23. http://dx.doi.org/10.1177/0899764012471585. Accessed December 1, 2015.

Jonas, Eva, Jeff Schimel, Jeff Greenberg, and Tom Pyszczynski. 2002. "The Scrooge effect: Evidence that mortality salience increases prosocial attitudes and behavior." Personality and Social Psychology Bulletin 28:1342-1353. http://dx.doi.org/10.1177/014616702236834.

Jung, Na Young, Soohyun Kim, and Soyoung Kim. 2014. "Influence of consumer attitude toward online brand community on revisit intention and brand trust." Journal of Retailing and Consumer Services 21: 581-589.

Just Giving. 2015. “Slacktivism - monster or myth? A free report”. London: Just Giving. Khazan, Olga. 2013. "UNICEF tells slacktivists: Give money, not Facebook likes”. The Atlantic, 30 April 2013. http://www.theatlantic.com/international/archive/2013/04/uniceftells-slacktivists-give-money-not-facebook-likes/275429/. Accessed January 20, 2014. 
Kottasz, Rita. 2004. "Differences in the donor behavior characteristics of young affluent males and females: Empirical evidence from Britain." Voluntas: International Journal of $\begin{array}{llll}\text { Voluntary } & \text { and } & \text { Nonprofit 18 } & \text { Organizations }\end{array}$ http://dx.doi.org/10.1023/B:VOLU.0000033180.43496.09.

Kristofferson, Kirk, Katherine White, and John Peloza. 2014. "The nature of slacktivism: How the social observability of an initial act of token support affects subsequent prosocial action." Journal of Consumer Research 40:1149-1166. http://dx.doi.org/10.1086/674137. Accessed December 1, 2015.

Lawrance, David. 2016. "How charities can make better use of social media”. The Guardian, 28 February 2013. http://www.theguardian.com/voluntary-sectornetwork/2013/feb/28/charities-social-media. Accessed February 2, 2016.

Lee, Yu-Hao, and Gary Hsieh. 2013. "Does slacktivism hurt activism?: the effects of moral balancing and consistency in online activism." Paper presented at ACM, Proceedings of the SIGCHI Conference on Human Factors in Computing Systems, Paris, France, April 27 May 2.

Leek, Sheena, and George Christodoulides. 2009. "Next-generation mobile marketing: How young consumers react to bluetooth-enabled advertising." Journal of advertising research 49: 44-53. http://dx.doi.org/10.2501/S0021849909090059.

Lovejoy, Kristen, Richard D. Waters, and Gregory D. Saxton. 2012. "Engaging stakeholders through Twitter: How nonprofit organizations are getting more out of 140 characters or less." Public Relations Review 38:313-318. http://dx.doi.org/10.1016/j.pubrev.2012.01.005. Accessed December 1, 2015. 
Mano, Rita S. 2014. "Social media, social causes, giving behavior and money contributions." Computers in Human Behavior 31:287-293. http://dx.doi.org/10.1016/j.chb.2013.10.044.

Maylor, Harvey, and Kate Blackmon. 2005. Researching business and management: A roadmap for success. Palgrave Macmillan.

Messing, Solomon, and Sean J. Westwood. "Selective exposure in the age of social media: Endorsements trump partisan source affiliation when selecting news online." Communication Research (2012). http://dx.doi.org/10.1177/0093650212466406.

Michikyan, Minas, Kaveri Subrahmanyam, and Jessica Dennis. 2014. "Can you tell who I am? Neuroticism, extraversion, and online self-presentation among young adults." Computers in Human Behavior 33:179-183. http://dx.doi.org/10.1016/j.chb.2014.01.010.

Pikkarainen, Tero, Kari Pikkarainen, Heikki Karjaluoto, and Seppo Pahnila. 2004. "Consumer acceptance of online banking: an extension of the technology acceptance model." Internet research 14:224-235. http://dx.doi.org/10.1108/10662240410542652.

Populus. 2016. "Public trust and confidence in charities". Charity Commission UK. https://www.gov.uk/government/uploads/system/uploads/attachment_data/file/532104/Public _trust_and_confidence_in_charities_2016.pdf Accessed April 18, 2017.

Reyniers, Diane, and Richa Bhalla. 2013. "Reluctant altruism and peer pressure in charitable giving." Judgment and Decision Making 8:7.

Ross, Craig, Emily S. Orr, Mia Sisic, Jaime M. Arseneault, Mary G. Simmering, and R. Robert Orr. 2009. "Personality and motivations associated with Facebook use." Computers in human behavior 25:578-586. http://dx.doi.org/10.1016/j.chb.2008.12.024. 
Rotman, Dana, Sarah Vieweg, Sarita Yardi, Ed Chi, Jenny Preece, Ben Shneiderman, Peter Pirolli, and Tom Glaisyer. 2013. "From slacktivism to activism: participatory culture in the age of social media”. Paper presented at AMC. CHI'11 Extended Abstracts on Human Factors in Computing Systems, Vancouver, May 7-12.

Sargeant, Adrian. 1999. "Charitable giving: Towards a model of donor behaviour." Journal of Marketing Management 15:215-238. http://dx.doi.org/10.1362/026725799784870351.

Sargeant, Adrian, John B. Ford, and Douglas C. West. 2006. "Perceptual determinants of nonprofit giving behavior." Journal of Business Research 59:155-165. http://dx.doi.org/10.1016/j.jbusres.2005.04.006.

Schervish, Paul G., and John J. Havens. 2001. "The mind of the millionaire: Findings from a national survey on wealth with responsibility." New Directions for Philanthropic Fundraising 2001:75-108. http://dx.doi.org/10.1002/pf.3205.

Seidman, Gwendolyn. 2013. "Self-presentation and belonging on Facebook: How personality influences social media use and motivations." Personality and Individual Differences 54:402-407. http://dx.doi.org/10.1016/j.paid.2012.10.009.

Shepherd, Robin-Marie, and Robert J. Edelmann. 2005. "Reasons for internet use and social anxiety." Personality and individual Differences 39:949-958. http://dx.doi.org/10.1016/j.paid.2005.04.001.

Smith, Joanne R., and Andreè McSweeney. 2007. "Charitable giving: The effectiveness of a revised theory of planned behaviour model in predicting donating intentions and behaviour." Journal of Community \& Applied Social Psychology 17:363-386. http://dx.doi.org/10.1002/casp.906. 
Stroebe, Wolfgang, and Bruno S. Frey. 1982. "Self- interest and collective action: The economics and psychology of public goods." British Journal of Social Psychology 21:121137. http://dx.doi.org/10.1111/j.2044-8309.1982.tb00521.x.

Vesterlund, Lise, Mark Wilhelm, and Huan Xie. 2008. Motives for charitable giving. Mimeo, University of Pittsburgh.

Vie, Stephanie. 2014. "In defense of "slacktivism”: The Human Rights Campaign Facebook logo as digital activism." First Monday 19. http://dx.doi.org/10.5210/fm.v19i4.4961.

\section{Author(s) Note}

Freya Samuelson-Cramp has around five years of work experience within the charity and non-profit sector. After leaving Great Ormond Street Hospital where she worked as a community fundraising assistant, Freya has been appointed as an account executive at the GOOD agency that provides bespoke marketing communication solutions for non-profit organizations.

Dr Elvira Bolat is a Senior Lecturer in Marketing at the Faculty of Management, Bournemouth University. Her teaching covers courses on both undergraduate and postgraduate levels. Her consultancy work and research interests cover a digitization of small and medium sized firms as well as digital transformation of consumption. 